\title{
THE POSTAL SECTOR AS A VECTOR OF FINANCIAL INCLUSION
}

\author{
by \\ G. d'ALCANTARA \\ University of Antwerpen, Belgium \\ and \\ A. GAUTIER* \\ University of Liege, Belgium
}

\begin{abstract}
Access to finance has become a major policy issue under the term Financial Inclusion. In this paper, we focus on the role of postal operators in financial inclusion policies. In developing countries, postal firms typically manage a dense network of counters with a unique coverage of rural areas where the banking sector is totally absent. We use a formal location model for postal counters and bank agencies to show that in rural areas a post-bank partnership can be a vector of financial inclusion and that this can be done profitably.
\end{abstract}

\section{Der Postsektor als ein Vektor für den Zugang zu Finanzdienstleistungen}

Der Zugang zu Finanzdienstleistungen ist unter der Bezeichnung Financial Inclusion zu einem wichtigen politischen Thema geworden. In diesem Beitrag befassen wir uns mit der Rolle von Postbetreibern auf dem Gebiet der Financial Inclusion-Politik. In Entwicklungsländern betreiben Postunternehmen normalerweise ein dichtes Netz von Postschaltern mit einer einzigartigen Flächenabdeckung ländlicher Gebiete, in denen der Banksektor gewöhnlich nicht präsent ist. Wir wenden ein formales Location-Modell auf Postschalter und Bankfilialen an, um zu demonstrieren, dass eine Postbank-Partnerschaft in ländlichen Gebieten ein Vektor für den Zugang zu Finanzdienstleistungen sein kann und dass eine solche Partnerschaft rentabel durchgeführt werden kann.

\section{El sector postal como vector de inclusión financiera}

El acceso a los servicios financieros se ha convertido en una política de desarrollo prioritaria bajo el nombre de Inclusión Financiera. En este artículo se estudia el papel que los operadores

The authors would like to thank M. Crew, O. Piley participants at the 2011 CRRI conference on postal and delivery economics held in Jersey and two anonymous referees for useful comments and suggestions. E-mail: agautier@ulg.ac.be 
postales pueden jugar en la inclusión financiera. En los países en desarrollo las empresas postales tienen, normalmente, una densa red de oficinas con una cobertura que se extiende al conjunto del territorio, mientras que el sector bancario está completamente ausente en las zonas rurales. Se utiliza un modelo de localización de oficinas de correos y de agencias bancarias para mostrar que, en las zonas rurales, una colaboración entre la empresa postal y un banco puede ser un vector de inclusión financiera y que puede, por añadidura, ser provechoso.

\section{Le secteur postal comme vecteur d'inclusion financière}

L'accès aux services financiers est devenu une politique de développement prioritaire sous le nom d'Inclusion Financière. Dans ce papier, nous étudions le rôle que les opérateurs postaux peuvent jouer dans l'inclusion financière. Dans les pays en développement, les entreprises postales ont typiquement un réseau dense de bureaux avec une couverture étendue de l'ensemble du territoire tandis que le secteur bancaire est totalement absent des zones rurales. Nous utilisons un modèle de localisation des bureaux de poste et des agences bancaires pour montrer que, dans les zones rurales, un partenariat entre l'entreprise postale et une banque peut être un vecteur d'inclusion financière et qu'il peut, de surcroit, être profitable.

\section{$1 \quad$ Introduction}

A lack of access to basic financial services such as credit or saving accounts forms a recognized and critical mechanism in generating persistent income inequality, poverty, as well as slower growth. Access to finance has become a major policy issue under the term Financial Inclusion. In this paper, we discuss financial inclusion policies with a particular focus on the role of postal operators as a vector of financial inclusion. This role has been recognized by key players including the Universal Postal Union (UPU).

In most countries, including developing countries, universal service obligations (USOs) regulate the location of postal counters, as accessibility of contact points is of prime importance. USOs often include an accessibility constraint such as a minimum travelling distance to a post office. As a result, the universal postal service provider typically manages a dense and unprecedented network of counters covering the whole national territory, and with a unique coverage of rural areas. ${ }^{1}$ Indeed, post office locations are largely determined according to geographical factors rather than population density. ${ }^{2}$ By contrast, financial institutions have retail offices only in the densest and richest part of the country. ${ }^{3}$ When transportation costs are high, as is the case, for instance, in developing countries, potential customers living outside these areas are thus

1 For instance, in the USA, 13\% of post offices are located in large urban areas and $87 \%$ are in small towns and rural areas.

2 Cohen et al. (2008) show that the average number of customers per pharmacy in the USA is more or less constant (around 1 pharmacy per 5,000 inhabitants) while for post offices the number varies from 454 in the first semi-decile to 24,000 in the last, with, on average, a post office for every 7,000 inhabitants.

3 In Italy, $26.8 \%$ of communes do not have a bank outlet while only $4.4 \%$ do not have a post office (Cohen et al. 2008). See also Adra and Sheehy (2011) for similar evidence from the USA. 
de facto excluded from the traditional banking sector because they cannot access it. ${ }^{4}$ Initiatives such as micro-finance institutions (MFIs) have tried to remedy the problem, although their isolated local scale limits their efficacy. In contrast, the postal operator is able to provide access to finance at a larger scale thanks to its unique network of counters, especially in rural areas.

In the less populated municipalities of the country, the universal service provider (USP) must maintain post offices, even if they operate neither profitably nor at full capacity. Evidence from selected countries in the Organization for Economic Cooperation and Development (OECD) demonstrates that in fact most post offices are non-profitable (Borsenberger et al. 2011). When a post office does not operate at full capacity, its otherwise unutilized potential can be used to provide financial services at low cost to consumers; in this way post offices are well placed to cheaply deliver financial services to financially excluded citizens. In order to do this, post offices must gain banking expertise, typically through either the constitution of a fully-fledged postal bank, or the formation of a partnership between a bank and the USP to provide financial products at postal counters (Ansón and Toledano 2011). In this way, a post-bank partnership can be used as a vector of financial inclusion in rural regions. As well as providing an essential service to financially excluded citizens, such partnerships can be profitable for both partners as the full cost of rural post offices is primarily financed through cross-subsidies from profit making segments of the postal market.

In this paper, we discuss the role of the postal operator as a vector of integration for unbanked citizens. Our objectives are to construct a formal location model for postal counters and bank agencies, and then to use this model in discussing financial inclusion policies. In our model, we particularly emphasize the role of transportation costs as developing countries, where financial inclusion is the most problematic, are often characterized by high transportation cost due to poor infrastructure. We will show that in rural areas a post-bank partnership can be a vector of financial inclusion and that this can be done profitably. Implications for universal service policies and relationships with other financial inclusion policies are then discussed.

Our paper is organized as follows. In section 2, the concept of financial inclusion is introduced, and successful inclusion policies involving postal operators in Brazil and India are briefly described; in section 3, we develop our location model for the banking and postal sectors; section 4 uses the location model to describe financial inclusion policies; and finally, section 5 concludes.

\section{$2 \quad$ Financial inclusion policies through postal networks}

\subsection{Definition of financial inclusion}

There exists a radical difference between the use of financial services in developing and industrialized countries. Data show that $91 \%$ of the US population have a bank account, as do on average $90 \%$ in the EU. In contrast, in urban Brazil the figure is 47\%, in Mexico City 21\%, in South Africa 32\%, and in Tanzania 6.4\%. Increasingly,

4 See Samara (2010) for evidences on banking penetration in developing countries. 
in both national and local development and poverty eradication policies, the important contribution of a broad-based financial sector in assisting economic development and poverty alleviation is recognized (United Nations 2006, World Bank 2008).

Financial exclusion can be caused by geographical factors, excessive prices, lack of education, but also by self-exclusion (Sinclair 2001). Financially excluded people come from a wide range of backgrounds such as marginal farmers, landless labourers, oral lessees, self-employed and unorganized sector enterprises, urban slum dwellers, migrants, ethnic minorities and socially excluded groups, senior citizens and women.

According to the United Nations (2006) the main goals of inclusive finance are characterized as follows:

- Access at a reasonable cost for all households and enterprises to an appropriate range of financial services including savings, short- and long-term credit, leasing and factoring, mortgages, insurance, pensions, payments, local money transfers and international remittances;

- Sound institutions guided by appropriate internal management systems, industry performance standards and performance monitoring by the market, as well as by sound prudential regulation where required;

- Financial and institutional sustainability as a means of providing access to financial services over time;

- Multiple providers of financial services, wherever feasible, so as to bring a wide variety of cost-effective alternatives to customers.

The capacity for everyone to choose and to use financial services, if desired, is a powerful instrument in stimulating economic activity. People can help themselves to increase their income, acquire capital, manage risk and work their way out of poverty. They can enjoy the benefits of payment services, transaction safety (for instance against theft), reliability, insurance, credit, and stored savings as a cushion in times of crisis. Access to a financial system can economically and socially empower people (especially the extremely poor) and assist people to contribute to their own development. Financial inclusion can improve welfare and quality of life for the individual, and become an engine of growth for the wider economy.

It is important to emphasize that inclusive finance covers a much wider spectrum than micro-finance alone. Rather, it encompasses a continuum of financial services providers, including post banks, state and agricultural banks, MFIs, non-governmental organizations (NGOs), insurance companies, credit unions, credit and savings cooperatives etc., all working within their comparative advantages to serve poor and low-income people, as well as micro and small-scale enterprises. In many countries, postal operators are considered to be a vector of financial inclusion, since their unique networks represent a trusted channel to reach those, who are financially excluded, especially in rural areas. The organization of post-bank partnerships differs across countries, from a fullyfledged postal bank in China to multiple partnerships in India, as reviewed by Piley and d'Alcantara (2011) and Ansón and Toledano (2011) in a more complete description of post-bank partnerships around the world. In the following section, we briefly describe the financial inclusion experiences in Brazil and in India. These case studies illustrate two different examples of how to implement financial inclusion and illustrate our proposed model. 


\subsection{Brazil}

At the end of the nineties, poverty reduction and financial inclusion were priorities for Brazil. The government decided to promote access to financial services through the national postal operator. The solution adopted was to connect banks with Correios, the postal operator, under the so-called 'Banking Correspondence' Legislation (1999) which allowed non-financial agents to contract with a financial institution to collect savings, receive and transfer request for loans and credit card applications, execute payments, bills, social security, deposits, transfers and withdrawals. The proposition was branded 'Banco Postal', Correios being one of the most trusted institutions in Brazil and preferred overall to banks. The choice of the banking partner in each of the Brazilian regions was made through a public tender. Bradesco, the largest Latin American bancassurer won the bid in each region, putting $\$ 250$ million on the table for the modernization of the counter network. Bradesco compensates Correios with a pre-determined fee for each transaction plus an upfront fixed payment.

Correios has a network of more than 6,192 branches, and the company's geographical cover is unique in Brazil, especially in rural areas where banks and other agencies have little presence. In $40 \%$ of the Brazilian municipalities, there is a post office but no bank branches. The Correios-Bradesco strategic alliance was led by the financial inclusion goal; the first counters to be opened were those based in localities with little or no financial service presence and nearly all counters were automated and connected in less than seven years. Statistics show that in Brazil, through the Correios-Bradesco strategic alliance, ten million accounts have been opened, mainly for the previously unbanked population. The Banco Postal ensures almost 95\% financial inclusion in the country.

The choice of banking partner has been put out to tender again in 2011. The Banco do Brasil won the deal and will replace Bradesco which has been providing financial services through Correios for almost 10 years. Banco do Brasil will pay $\$ 1450$ million for the privileged access to the postal branches for the next five and half years. Among the new products to be launched in Brazilian Post are credit cards and prepaid cards.

\subsection{India}

Both the Central Government and the Reserve Bank of India (RBI) have been pursuing financial inclusion for decades, through rural cooperatives in the 1950s, social contracts with banks in the 1960s, and expansion of the bank branch network in the 1970s and 1980s, as described in Burgess and Rohini (2005). In spite of these efforts, at the turn of the century an average $60 \%$ of the country's population did not yet have bank accounts and nearly $90 \%$ did not or could not take out loans. Therefore, in 2006 the Indian Government took radical steps to make financial inclusion its top priority, putting the RBI in charge of coordinating a new financial inclusion policy. The policy defined two functions, the Business Facilitator $(\mathrm{BF})$ and the Business Correspondent (BC), in order to create an extensive network of village-level intermediaries such as non-profit MFIs or Civil Society Organizations. While BFs would facilitate the linking and opening of bank accounts by unbanked individuals, the BCs would mobilize deposits and disburse credits on behalf of the banks. Banks and India Post could then use this new structure to expand their outreach. 
India Post has a long tradition in finance, having offered saving accounts since 1882. It plays an important role in India's financial inclusion policy because it has a unique presence in rural areas ignored by the traditional banking sector (only $5.2 \%$ of the 165,000 Indian villages host a bank). India Post has 155,000 post office counters of which $90 \%$ are situated in rural areas, as well as 206 million savings accounts with a total balance of $\$ 126$ billion. All its post offices should be automated in the next five years. India Post contributes to financial inclusion both directly and through partnerships with commercial banks; the company's financial services are organized along four axes: banking (including savings and remittances), micro-finance and wage payments, micro-insurance, and other products from allied suppliers (fund management with UTI, pensions with ICICI, insurance with Oriental Insurance Company, MFIs and regional banks). Recently India Post teamed up with three banks to issue and operate pre-paid debit cards targeted at a low-income population. Other alliances and contracts include unique identification SIM cards, mobile telephony, and internet delivery. Partnerships are central to India Post, whose counter network acts as a conduit, and likewise essential to the distribution of financial products in rural areas. Over the last two years, India Post has opened 35 million savings accounts, mainly for people previously excluded from the banking system.

Though the structure of the bank-post partnership is different, the Brazilian and the Indian experience show that, in a country where financial institutions are absent from rural areas, the postal sector and its unique coverage of the population can be used to bring basic financial products to the financially excluded. In the next sections, we develop a formal model of banking and postal coverage of the country to show that such a financial inclusion strategy can be developed profitably by the post.

\section{$3 \quad$ The model}

In this section, we develop a formal location model that will be used as a starting point for our discussions on financial inclusion in section 4 . The aim of the model is to characterize the locations of postal and bank outlets in a country with an heterogeneous population.

\section{$3.1 \quad$ Population}

The hypothetical country in question is represented by a continuum, $[0, \bar{x}]$, of municipalities. Municipalities are heterogeneous with respect to the number of inhabitants. Let us denote by $x$ an arbitrary municipality. The population of $x$ is $N(x)$, and municipalities are ranked according to their population: $N^{\prime}(x) \leq 0$. Figure 1 represents the distribution of inhabitants across the country. The total population is represented by the area below the curve $N(x)$.

There are two categories of inhabitants: those who are financially literate, and those who are not. Financial (il)literacy is akin to digital (il)literacy and refers to the knowledge and capabilities necessary to understand and manage basic financial products (e.g. saving accounts, loans, insurance products). The benefit derived from the consumption of financial services, and the resultant willingness to pay for the services 


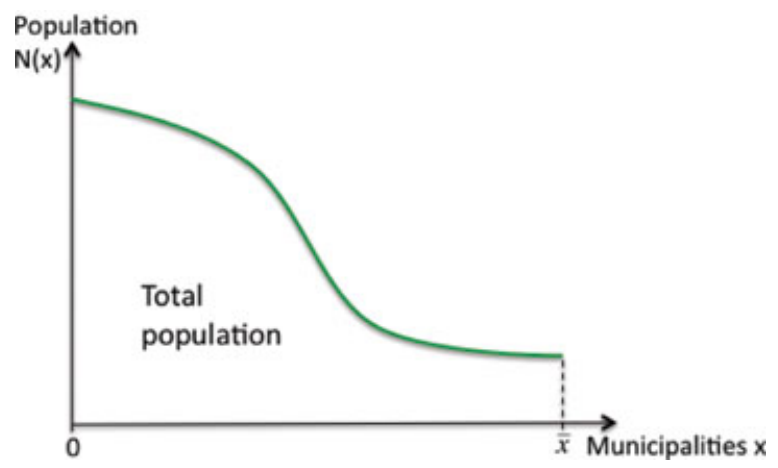

Figure 1 - Distribution of inhabitants across the country.

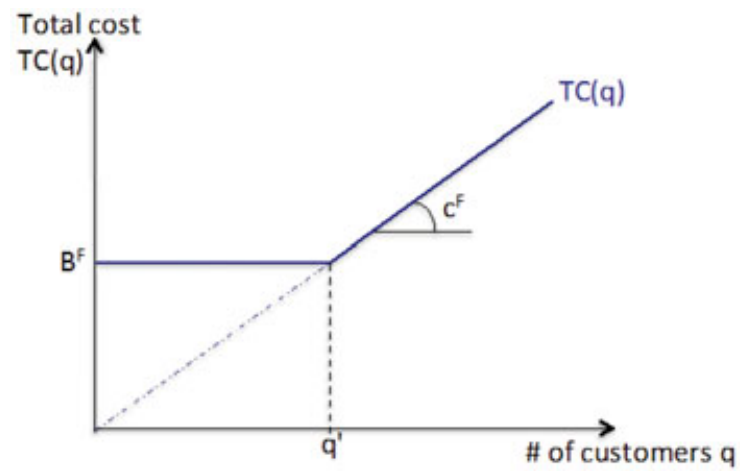

Figure 2 - Bank sector cost function.

differs between the two groups (see after section 3.2). In a municipality, $x$, the proportion of financially illiterate inhabitants is equal to $\alpha(x)$ and, for simplicity, we will assume that this proportion is constant across the country: $\alpha(x)=\alpha$ for all $x$. We distinguish two groups in the population to enlighten the fact that financial exclusion has different causes, be it illiteracy or inaccessibility of contact points, requiring different policies.

\subsection{The financial sector}

Banks locate their commercial outlets within the municipalities, and use their retail networks to provide financial services to consumers. There are indivisibilities in the construction of a bank outlet (building, IT facilities, minimum staff level etc.) resulting in a fixed cost, $B^{F}$, per outlet. Any single outlet has the capacity to provide financial services to $q$ ' consumers. The provision of service to an additional consumer involves an extra cost, $c^{F}$ (additional staff, extra space etc.). We assume that $B^{F}=c^{F} q$ ? Thus, the total cost of a banking outlet serving $q$ customers is $T C(q)=\operatorname{Max}\left[B^{F}, c^{F} q^{\prime}\right]$. This cost function is represented in Figure 2.

A consumer either subscribes to the financial services, at price $p^{F}$, or chooses not to. The total demand for banking services is thus equal to the number of subscribing 
inhabitants. The decision to be included in the financial sector depends on three factors: (1) the price of financial services, $p^{F}$; (2) the accessibility of contact points; and (3) the benefit derived by the consumer from the consumption of financial services, $S$. Financially literate inhabitants are characterized by a higher benefit, $\left(S^{H}\right)$, than financially illiterate ones, $\left(S^{L}\right)$.

$U^{F}(x)$ is the net utility a consumer, living in $x$, derives from the consumption of financial services offered by a bank outlet located in $k$. Formally, $U^{F}(x)$ can be written as follows:

$$
U^{F}(x)=S-p^{F}-t d(x, k)
$$

Where $S \in\left\{S^{L}, S^{H}\right\}$ and $d(x, k)$ is the distance between the consumer's location, $x$ and $k$. The travelling cost per unit of distance is equal to $t$. This cost depends, among other factors, on the level of infrastructure development within the country. A country with less developed infrastructure will be characterized by a higher transportation cost, $t$. A consumer is included in the financial sector if $U^{F}(x) \geq 0$. Finally, we assume that $S^{H} \geq c^{F} \geq S^{L}$, that is, that a financially illiterate inhabitant will not be included in the financial sector even if the services are supplied at marginal cost in their municipality.

The banking sector is assumed to be competitive in our model. Perfect competition implies marginal cost pricing and zero profit for banks; moreover, at equilibrium, the retail network should be such that it is not possible to operate an additional outlet profitably. Marginal cost pricing is only compatible with the zero profit condition if banking outlets operate at full capacity. In a competitive banking sector $p^{F}=c^{F}$ and each bank branch serves at least $q$ ' customers. Financially illiterate inhabitants are thus de facto excluded from the banking sector. The following proposition describes the location of the bank branches in the country under the competitive assumption.

Proposition 1: Based on the location of bank branches, the country can be divided in three regions:

1. An urban region $\left[0, x^{u}\right]$ where there is (at least) one banking outlet per municipality. Consumers do not incur any travel costs in accessing financial services.

2. A suburban region $\left[x^{u}, x^{s}\right]$ where all consumers are covered by the banking network but outlets are not located in every municipality. Some consumers in the suburban region therefore incur travel costs.

3. A rural region $\left[x^{s}, \bar{x}\right]$ where the banking sector does not provide services and consumers are consequently unbanked.

In all the municipalities where, at the competitive price $p^{F}=c^{F}$, the number of potential consumers, $(1-\alpha) N(x)$, is at least equal to $q$, there is (at least) one banking outlet. ${ }^{5}$ The urban region is thus defined as $\left[0, x^{u}\right]$, where $x^{u}$ is the solution of $(1-\alpha) N\left(x^{u}\right)=q^{\prime}$. In the urban region, all the financially literate citizens are customers of the banking sector and only the financially illiterate individuals are unbanked. Moreover, customers do not incur any transportation costs.

5 If there are more than $n q$ ' customers in a municipality $x$, the banking sector can indifferently operate one or $n$ outlets at $x$. 


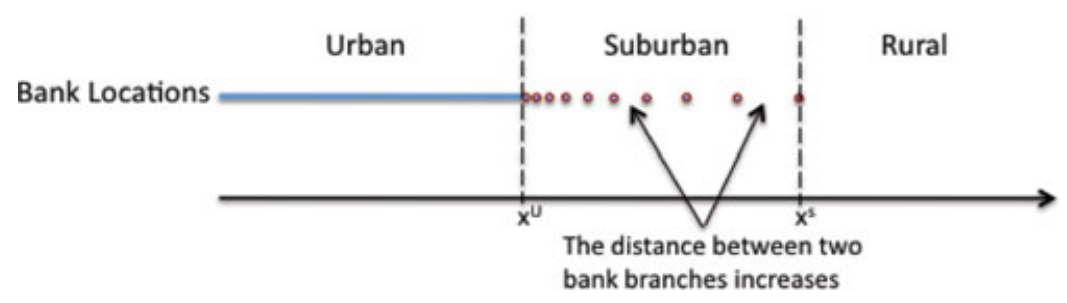

Figure 3 - Banking network location.

In the municipalities outside the urban region, the number of potential customers is not high enough to profitably operate a bank office in every municipality. The bank retail network will therefore be less dense, and not all the municipalities will host a bank branch. As a consequence, some consumers incur transportation costs.

The suburban region is composed of the municipalities in $\left[x^{u}, x^{s}\right]$ and this part of the country hosts $n$ bank branches. A bank, $i$, located in municipality $x_{i}$, is at a distance $2 d_{i-1}$ from the closest outlet to the west and at a distance $2 d_{i}$ from the closest outlet to the east. Given that consumers always go to the closest bank, the number of consumers served by branch $i$ is $N_{i}=(1-\alpha) \int_{x_{i}-d_{i-1}}^{x_{i}} N(x) d x$. The number and the locations of bank branches in the suburban region is characterized by the following equations:

$$
\begin{gathered}
N_{i}=q^{\prime} \\
x_{0}=x^{u} \text { and } d_{0}=d_{1} \\
S^{H}-c^{F}-t d_{n}=0
\end{gathered}
$$

Equation 1 states that bank branches must operate at full capacity. When the population decreases, in order to attract $q^{\prime}$ customers a bank must cover a larger area of municipalities. Thus, the distance between two banks, measured by $2 d_{i}$, increases as $N(x)$ decreases. Equations 2 and 3 are boundary conditions: (2) defines the boundary between the urban and the suburban regions, and (3) characterizes the end of the suburban region. When the distance a consumer must travel to reach a bank becomes too large, consumers no longer find it profitable to buy financial services at the bank. The longest acceptable journey for a consumer is $d_{n}=\left(S^{H}-c^{F}\right) / t$. Given this, the boundary of the suburban region is defined as $x^{S}=x_{n}+d_{n}$. In the suburban region, all the financially literate citizens have access to the financial sector, although they derive a lower net utility from the consumption of financial services than urban citizens because financial services are more costly to access.

Finally, in the rural region, $\left[x^{s}, \bar{x}\right]$, municipalities are not populated enough to have profitable banks and the financial sector simply does not cover the region at all. All citizens, financially literate or not, are thus excluded from the financial sector in the rural region.

The location of bank branches is illustrated in Figure 3. 
Country characteristics (including population density and travel costs) ${ }^{6}$ and the percentage of financially illiterate inhabitants determine the relative size of the urban and suburban regions. We can therefore establish that:

Proposition 2: A decrease in the travelling cost t leads to an increase of the suburban region and a larger coverage of the financial sector.

Travelling costs play an important role in the coverage decision of the banking sector and therefore on the extent of financial exclusion. As there are indivisibilities in the construction/operation of a bank outlet, the financial sector cannot develop its network profitably when population density is low and transportation costs are high. Better infrastructure and lower transportation costs lead to a larger coverage of the population by the financial sector. A decrease in the indivisibilities linked to a bank branch would have the same effect.

\subsection{The postal sector}

In the postal sector, the operator in charge of the Universal Postal Service, called hereafter the Universal Service Provider (USP), faces competition from alternative postal operators and from competing technologies (such as the internet). However, competition is usually limited to a subset of products and to some parts of the country, usually the densest regions. For the remaining products and regions, the USP still operates a monopoly; one reason for this absence of competition is the non-profitability of some products that the USP must offer as part of its universal service obligations. It is our contention that the USP offers a composite universal service product at price $p^{P}$ in its offices, and that the USP remains a monopolist for this universal service product. For the moment, we will not consider the possibility that the USP offers financial service in its post office network.

Just as for bank outlets, there are indivisibilities in the construction of a post office. A post office has a fixed cost, $B^{P}$, and the capacity to serve $r^{\prime}$ customers. An additional customer is served at a marginal cost of $c^{P}$. We assume that $B^{P}=c^{P} r^{\prime}$. The cost of a post office serving $r$ customers is $T C(r)=\operatorname{Max}\left[B^{P}, c^{P} r^{\prime}\right]$. The cost function for the USP is similar to the cost of the banking sector represented in Figure 2.

The utility which a consumer located in $\mathrm{x}$ derives from the consumption of postal services is

$$
U^{P}(x)=S^{P}-p^{P}-t d(x, k)
$$

Where $S^{P}$ is the gross benefit derived from the consumption of the universal service postal product; $p^{P}$ is the price of the postal product; $d(x, k)$ is the distance between the consumer's location, $x$, and the closest postal office located in $k$; and $t$ is the travel cost per unit of distance.

The government imposes a series of universal service obligations on the USP. In our model these obligations include:

6 Countries are heterogeneous with respect to the repartition of the population within the territory (see d'Alcantara and Gautier, 2008 for examples). 
1. Universal coverage/accessibility of postal counters: every citizen should have access to a postal counter. ${ }^{7}$ That is, consumers cannot be located further than $d^{*}$ from a post office. Given that consumers shop at the closest office, the maximum allowed distance between two post offices is therefore $2 d^{*}$.

2. Uniform price: the universal service product must be offered at a uniform price.

3. Affordable price: the price level is capped. In the model, we will assume that the price should be set at a level that guarantees a nil profit for the USP.

Given these assumptions, postal services are offered at a price above the marginal cost, and some post offices operate below full capacity (e.g. with staff waiting for customers at the counter).

In a similar though not identical way to the banking network, the postal network can be divided into three zones. The following proposition describes the location of the postal outlets in the country.

Proposition 3: Based on the location of postal outlets, the country can be divided in three regions:

1. A dense zone $\left[0, x^{d}\right]$ where the USP has a counter in every municipality.

2. An intermediate zone $\left[x^{d}, x^{I}\right]$ where not all municipalities hold a post office, and all post offices operate at full capacity. In this intermediate zone, the distance between two offices is less than or equal to $2 d^{*}$ i.e. the accessibility constraint is not binding.

3. A non-dense zone $\left[x^{I}, \bar{x}\right]$ where the distance between two post offices is $2 d^{*}$ and post offices no longer operate at full capacity.

To finance the loss-making counters located in remote areas, the USP must charge a price above its marginal cost $p^{P}>c^{P}$. Thus, if $S^{P}>p^{P}$, in every municipality where $N(x) \geq$ r', post offices are profitable, and there will be (at least) one post office in every municipality that satisfies this condition. The dense zone is thus defined as $\left[0, x^{d}\right]$ where $x^{d}$ solves $N\left(x^{d}\right)=r^{\prime}$.

In the intermediate zone, a post office in every municipality would imply that post offices do not operate at full capacity. Therefore, the USP will space out its post offices to attract more customers at each contact point. The main characteristic of the intermediate region is that post offices still operate at full capacity (see 4 , below) but the distance between two offices is capped 6 , also below). In the intermediate zone, formally defined as $\left[x^{d}, x^{I}\right]$, the number of post offices, $m$; their localization, $x_{i}$; the distance between two post offices, $2 d_{i}$; and the size of the intermediate region are determined by the following equations:

$$
\begin{gathered}
\int_{x_{i}-d_{i-1}}^{x_{i}+d_{i}} N(x) d x=r^{\prime} \\
x_{0}=x^{d}, d_{0}=d_{1} \\
d_{m}=d^{*}
\end{gathered}
$$

7 Existing regulations may formulate this in various ways according to distances or transportation times depending on the topography of the country territory and the distribution of the population across it. 


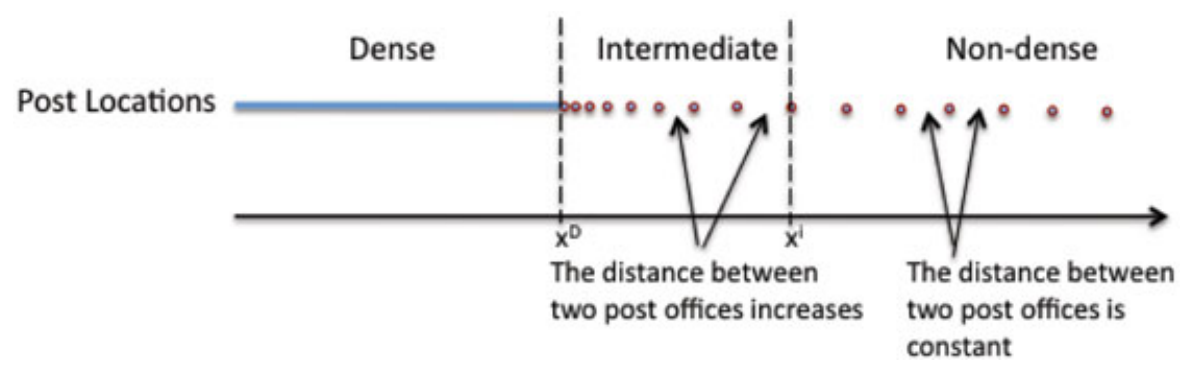

Figure 4 - Postal network location.

To maintain post offices at full capacity, the USP must increase the distance between the offices as the population density declines. At some point, the USP will reach the maximum distance constraint and be unable to further space out offices to increase the number of customers; the intermediate zone ends when this constraint becomes binding. In the intermediate zone, consumers have to travel less than $d^{*}$, the maximal regulated distance, and the post offices operate at full capacity. In the non-dense zone, the distance between offices is the maximum allowed and these offices operate below full capacity, i.e. they would be able to serve additional customers at no additional cost. The boundary between the intermediate and the non-dense zones is formally given by $x^{I}=x_{m}+d^{*}$.

The location of postal counters in the country is represented in Figure 4.

Comparing the distribution of postal and banking offices (Figures 3 and 4), it appears that (i) part of the country is not covered by the banking sector while post offices are ubiquitous; and (ii) under a reasonable assumption of demand and costs, the postal network will be denser than the banking sector. This echoes the observed difference in the density of postal and banking counters. Post offices are everywhere while banks are located only in the densest and richest part of a country.

The profit of the USP at price $p^{p}$ is given by:

$$
\pi=p^{P} \int_{0}^{\bar{x}} N(x) d x-c^{P} \int_{0}^{x^{I}} N(x) d x-\frac{\left(\bar{x}-x^{I}\right)}{2 d^{*}} B^{P}
$$

The first term is the postal revenue (on the assumption that all citizens are customers of the USP which formally corresponds to the condition $p^{P}<S^{P}-t d^{*}$ ), the second term is the cost of serving the customers in the dense and the intermediate zones, and the last term is the cost of serving customers in the non-dense zone. This cost is a fixed cost.

According to the definition of universal service, the USP must charge all users the same price and this price must be set at the lowest possible level possible without resulting in a loss for the USP. Because of the fixed cost, the price is above the marginal cost, $p^{P}>c^{P}$, and the mark-up depends on the specifics of the accessibility constraint. Suppose that the regulator imposes a more severe accessibility constraint on the USP: in this case the intermediate zone shrinks and the non-dense zone expands. Moreover, the density of postal counters must also increase in the non-dense zone. A more accessible 
network implies that there will be more offices that operate below full capacity. We therefore conclude:

Proposition 4: If the regulator imposes stronger accessibility constraints, a lower $d^{*}$, or if the travel costs increase, the intermediate zone consequently shrinks ( $x^{I}$ decreases) and the price paid by postal users increases.

\subsection{Financial exclusion} equal to

In the hypothetical country in question, the number of unbanked citizens is

$$
U B=\alpha \int_{0}^{x^{s}} N(x) d x+\int_{x^{s}}^{\bar{x}} N(x) d x
$$

That is, all the financially illiterate inhabitants of the urban and suburban regions (first term in the above equation) and all the inhabitants of the rural region (second term). All these people have no access to the banking sector either because they do not have the capabilities to, or because it is too costly for the financial sector to provide them with access to banking services. In the next section, we discuss different policies that aim at including more inhabitants in the financial sector with a particular focus on post-banking partnership. As we will see, financial inclusion policies must necessarily be multidimensional.

\section{$4 \quad$ Financial inclusion policies}

As mentioned, financial inclusion has become a major policy objective. Access to financial services is seen as a mean to reduce poverty and stimulate economic growth. Accordingly, financial services can be seen as a 'merit good' and public policies should be designed to include more citizens in the financial sector as the market leads to exclusion, due to indivisibilities and/or financial illiteracy.

\subsection{Accessibility of financial services through the postal retail network}

\subsubsection{The post bank partnership}

In the rural region the banking sector cannot operate profitably and all inhabitants are consequently unbanked. At the same time, the rural region is covered by the postal network, and the post offices do not operate at full capacity. This means that existing post offices have spare capacities to provide postal services; if it is possible to convert these postal capacities into financial capacities, then the postal network can be used to provide services to at least some of the unbanked inhabitants of the rural region.

An association between one (or several) banks and the USP (as in Brazil or India) can be mutually profitable and socially beneficial. The bank provides its expertise in the supply of financial services; the USP offers its cheap retail capacity for the distribution of the bank's products. Key to the success of this kind of partnership is the ability for 
the USP to provide financial services at a lower cost than the banking network. Let us discuss this point in greater detail.

In the non-dense region, a post office located in $x$ serves $\int_{x-d^{*}}^{x+d^{*}} N(x) d x$ customers and, by definition, this number is smaller than the post office's capacity, $r$ '. Each post office in the non-dense region has the potential to serve $r^{\prime}-\int_{x-d^{*}}^{x+d^{*}} N(x) d x>0$ postal customers at a zero marginal cost. Under a post-bank partnership, financial services can be offered using these otherwise unutilized capacities. The provision of financial services in a post office involves lower costs than in the banking network because parts of the expense (staff, building costs, IT etc.) are already covered. Let us assume that the USP is able to supply financial services to $r^{\prime}-\int_{x-d^{*}}^{x+d^{*}} N(x) d x>0$ customers in the nondense zone at a cost of $d^{F}<c^{F}$. Redeploying existing office and staff capacities from postal operations to financial operations involves lower costs than establishing new capacities. Thus in the non-dense region, financial services can be provided (up to the capacity limit) by the USP at a lower cost than the financial sector. The postal retail network can thus be used to sell potentially low priced financial products. But this reasoning only holds true in the non-dense region. When a post office already serves $r$ ' customers (or more), the provision of financial services to additional customers involves extra cost and one can reasonably surmise that these extra costs are higher than they would be in the more specialized banking network.

Suppose that financial services are provided to customers in the rural region at price $p^{F}$ through the postal network involving a cost $d^{F}$ per customer. The potential profit from the post-bank partnership can be measured by:

$$
\mu=\left[\frac{\left(\bar{x}-x^{I}\right)}{2 d^{*}} r^{\prime}-\int_{x^{I}}^{\bar{x}} N(x) d x\right]\left(p^{F}-d^{F}\right)
$$

The first term under brackets in Equation 7 is the total capacity left for financial operations i.e. the total capacity of the $\left(\bar{x}-x^{I}\right) / 2 d^{*}$ postal offices installed in the non-dense region minus the capacity used for postal services; the second term is the profit per customer. Clearly enough, these potential profits increase with the postal network density as a decrease in the minimal distance $d^{*}$ creates additional capacity, financed by postal products, to supply profitably financial products in post offices. $\mu$ in the above equation is the total surplus from the partnership that must be shared between the two partners either by the mean of a fee for service or by an upfront payment made by the bank to the post. The surplus from the partnership is calculated at the margin, taking for granted that the post offices are already financed by the revenue from the postal sector.

The price at which financial services are offered by post offices must at least cover the marginal cost of the service. On the other hand, the price of the financial services offered by the USP determines the global demand for these services. Any price above the marginal cost, $d^{F}$, and below $S^{H}$ induces a positive demand and therefore generates strictly positive profits for the post-bank partnership. Financial services offered at post offices are thus part of a profit-making activity. A partnership between a bank and the postal operator to provide financial services in remote areas is mutually profitable, while a bank alone would be unable to supply financial services profitably. There are economies of scope between financial and postal services due to the indivisibilities in the construction of a retail outlet and the post-bank partnership is able to exploit these 
economies profitably. This explains why the Brazilian Post managed to run at a profit its partnership with a bank to distribute financial products in rural regions. Financial inclusion policy implemented through post offices is a socially valuable and profit-making activity.

In the non-dense region the USP can offer, in partnership with a bank, financial services to at least some of the unbanked population. The potential for financial inclusion is limited by the spare capacity available at post offices, which in turn depends on the strength of the universal service constraints (see after). In the rural areas, the existing postal network can be used to offer financial services at low cost, and the postal network is thus a vector of financial inclusion. Outside this area, where banks are available and post offices operate at full capacity, the main cause of financial exclusion is not the accessibility of financial services but other factors like financial illiteracy. In this case, the post-bank partnership is of little help and financial inclusion should be reached by another mean.

\subsubsection{Implications for USO policy}

The ability of the postal operator to provide financial services at low cost is intrinsically linked to the universal service policy. The USO imposes the maintenance of a dense network of post offices in the less populated areas of the country. This generates a substantial amount of fixed cost that the USP covers by charging a positive mark-up on the postal products that it offers, and loss-making postal outlets are thus financed by postal consumers paying higher prices. There are cross-subsidies from the postal activity to the financial activity as the cost of post offices is fully allocated and financed by postal products. These cross-subsidies implied by the USO policies are partially paid to the commercial banks as they collect part of the benefit from the partnership with the postal operator.

With the post-bank partnership, the postal operator collects extra revenue and the financial burden of the accessibility constraint is thereby reduced. However, even with the extra income from financial activities, post offices in the non-dense region may remain unprofitable. ${ }^{8}$ Furthermore, market expansion and technological innovations have intensified competition in postal markets, resulting in declining transaction volumes for the USP. This puts pressure on the historical postal operator and on its ability to finance a universal postal service. ${ }^{9}$

In a context of more severe competition for communication services and additional pressures to close non-profitable post offices, the revenue collected by the USP from its financial activity proves to be useful to maintain the retail network. By exploiting economies of scopes, the postal operator can generates additional income to sustain its post office network. Despite that, a regulator is unlikely to impose more stringent

8 Borsenberger et al. (2011) estimate the number of postal retail outlets that a commercial postal firm would maintain in the absence of accessibility constraint. They show that, in the absence of USO, the number of post offices would be decreased by more than $60 \%$ in most of the countries considered. This clearly illustrates that even for countries were the post bank generates a substantial share of the income and profit, many retail offices remain non-profitable.

9 For Crew and Kleindorfer (2006), intensified competition calls for a reform of the universal service, and they focus in particular on the accessibility of contact points. Crew and Kleindorfer suggest that the number of contact points ought to decrease. 
accessibility constraints (a lower $d^{*}$ ) on the postal firm. The reason is that the postbank partnership is profitable given the existing postal network because it is financed by postal users, but not if it necessitates a large network expansion. In a world where e-substitution erodes the mail volume handled by the postal operator, diversification to exploit the economies of scope in post offices is useful to maintain the retail network but it cannot be extended without imposing an additional financial burden on the postal users, which is unlikely to be done. Furthermore, the development of electronic communication channels erodes the consumer's willingness to pay for postal services and may threaten the financial viability of the universal service obligations. In this context, alternative sources of income such as the distribution of financial products in post offices can be useful to sustain the universal service.

\subsection{Other financial inclusion policies}

The post-bank partnership is only a partial solution to the financial inclusion. Capacities available for financial products are limited and may not be sufficient to reach the whole population. Furthermore, capacities are only available in the rural areas and exclusion of illiterate people in city centres cannot be tackled by making financial products in postal outlets. The postal sector is only one vector of financial inclusion that must be combined with other policies. In this section, we review a few. We focus on the role of infrastructure and on mobile banking that are two alternative solutions to bring financial services in remote areas and that can be considered as substitutes to the bank post partnership. As we said, such a partnership requires a nationwide network of post offices and this is not necessarily in place in all developing countries, especially in Africa. Next, we focus briefly on financially illiterate customers that are excluded not (only) because services are not provided but because they lack the necessary competence.

\subsubsection{Infrastructure and indivisibilities}

The banking sector does not have retail facilities in the rural region because installing a banking outlet involves some fixed cost that cannot be recovered because transportation costs are too high to create a sufficiently large demand. Samara (2010) provides indicators of availability of banking services (number of bank outlets per inhabitant, number of ATM per inhabitant). Clearly, the availability index is linked to infrastructure quality and transportation facilities. Thus, policy initiatives that would be taken to reduce the transportation costs may in the long run contribute to the development of the banking sector. Likewise, the possibility to reduce the indivisibilities, for instance by offering multi-service outlets would increase the penetration of the banking sector in the rural area.

\subsubsection{Mobile and other information technologies}

Another promising way to develop financial services in poorly connected areas is to use mobile phones as a medium for exchanging money. The mobile technology can be used to store money and make electronic payment and it must be combined with a physical network of agents where it is possible to make cash deposits and withdrawals. The most successful mobile banking experience is the M-PESA system developed in 
Kenya. ${ }^{10}$ The M-PESA system allows the owner of a mobile phone to store and send money by phone and to deposit or withdraw money from a registered agent, for instance a mobile device shop. The system requires little infrastructure; the mobile phone needs to be equipped with a SIM card with the M-PESA application and the user must fill in an application form. The system started in 2006 and it should be considered as a success. It allows users to send or withdraw money at over 23,000 retail outlets and this must be compared to the 1,000 existing bank branches in the country. M-PESA has become the main provider of financial services for poor people in Kenya. Following M-PESA, mobile banking experiences spread around the world.

\subsubsection{Education}

Financial inclusion through post offices is not a panacea. The capacity to serve people remains limited, and only citizens in remote areas are positively affected. Financial inclusion of the illiterate population in urban and suburban regions requires other policies; such regions have banks, and so physical accessibility is less of an issue. Instead, the problems here centre around people who lack the capabilities to be included in the traditional financial sector, and in any case the postal sector is unable to distribute financial products at lower cost in these regions. Thus, financial inclusion in these regions requires education campaigns or the development of low-cost banks dedicated to the needs of the poorest. Financial inclusion in this case is no longer a profitable activity and requires an active public policy (see Kempson et al. 2004).

\section{Conclusion}

In cities there is no problem of physical access to financial services as banks are numerous, but there is a very real problem of education: some citizens lack financial education, and have a low willingness to pay for financial services. Dedicated policies must be targeted to those groups of citizens, and the postal sector may not be the most appropriate vector of inclusion. Education is costly and awareness campaigns must be subsidized, either by the government or by firms (if they can recover their investment through higher prices). In rural regions, accessibility of financial services is the main issue: when the universal service provider is compelled to maintain a dense network ${ }^{11}$ that does not operate at full capacity the postal sector can be a useful part of the financial inclusion strategy. With a post bank partnership, financial services can then be offered at a low price by the postal network. Making financial services accessible through post offices is a mutually profitable partnership between the universal service provider and banks.

In this paper, we have sought to provide a formal model of financial inclusion that focuses on such a post bank partnership. The main use of such a formal model is in quantifying the cost and benefits of the partnership. For that, we qualify the locations of bank outlets and post offices in the country, assuming that there are indivisibilities in the construction of a retail facility. We developed our model in the context of a competitive

10 See Dittus and Klein (2011) for a discussion.

11 And in some countries, mainly Africans, the postal sector is even absent from rural regions. 
banking sector and a regulated postal sector. We show that the postal operator must maintain a dense network of post offices in the rural area. By contrast, the banking sector is totally absent from the rural area because the low population density prevents it to operate profitably. Post offices in remote place operate below full capacity and the infrastructure costs are supported by postal users. The postal operator can exploit economies of scope to offer financial products in the post offices at a lower cost than in a bank outlet. Economies of scope make the post bank partnership profitable and financial inclusion can be achieved profitably. This partnership requires an existing network of post offices to be implemented and, when this condition is met for instance in Brazil or in India, the postal sector can be a powerful vector of financial inclusion.

\section{REFERENCES}

ADRA M. and SHEEHY R., 2011, 'A framework for optimizing and modernizing the U.S. postal service retail network', paper presented at the 19th conference on Postal and Delivery Economics, Jersey, June 2011.

D'ALCANTARA G. and GAUTIER A., 2008, 'National postal strategies after a full postal market opening,' in M. A. Crew and P. R. Kleindorfer, eds, Competition and Regulation in the Postal and Delivery Sector, Cheltenham, UK and Northampton MA, USA: Edward Elgar, 167-186.

ANSÓN J. and TOLEDANO J., 2011, 'Financial inclusion and postal banking: is the survival of posts also there?', in M. A. Crew and P. R. Kleindorfer, eds, Reinventing the Postal Sector in an Electronic Age, Cheltenham, UK and Northampton MA, USA: Edward Elgar, 319-335.

BORSENBERGER C., JORAM D. and ROY B., 2011, 'How many outlets if the USP does not face any USO? A cross-country comparison', in M. A. Crew and P. R. Kleindorfer, eds, Reinventing the Postal Sector in an Electronic Age, Cheltenham, UK and Northampton MA, USA: Edward Elgar, 123-141.

BURGESS R. and ROHINI P., 2005, 'Do rural banks matter? Evidence from the Indian social bank experiment', American Economic Review, 95, 780-795.

COHEN R., DI PAOLA L., SHEEHY R. and VISCO COMANDINI V., 2008, 'The distribution of Post Offices in Italy and the United States', in M. A. Crew and P. R. Kleindorfer, eds, Competition and Regulation in the Postal and Delivery Sector, Cheltenham, UK and Northampton MA, USA: Edward Elgar, 36-46.

CREW M. A. and KLEINDORFER P. R., 2006, 'Approaches to the USO under entry', in M. A. Crew and P. R. Kleindorfer, eds, Liberalization of The Postal And Delivery Sector, Cheltenham, UK and Northampton MA, USA: Edward Elgar, 1-18.

DITTUS P. and KLEIN M., 2011, 'On harnessing the potential of financial inclusion. The case of mobile payments', BIS Working Papers No 347.

KEMPSON E., ATKINSON A. and PILEY O., 2004, 'Policy-level response to financial exclusion in developed economies: lessons for developing countries', The Personal Finance Research Centre, University of Bristol, Bristol UK.

PILEY O. and d'ALCANTARA G., 2011, 'Perspectives for postal financial services in their historical context', Finance \& the Common Good/Bien Commun, forthcoming. 
SAMARA M., 2010, 'Index of financial inclusion', Discussion Paper 10-05, Centre for International Trade and Development, Jawaharlal Nehru University, India.

SINCLAIR S., 2001, 'Financial exclusion: an introductory survey', Edinburgh: Centre for Research into Socially Inclusive Services (CRSIS), Edinburgh College of Art/Heriot Watt University.

UNITED NATIONS, 2006, 'Building Inclusive Financial Sectors for Development', New York.

WORLD BANK, 2008, 'Finance for All? Policies and Pitfalls in Expanding Access', A World Bank Policy Research Report, Washington DC. 